\title{
Implementation of the Pancasila Lifestyle for the Life of the Millennial Generation 4.0 in the Era of Globalization
}

\author{
Rizki Alivia Putri Widodo ${ }^{1}$, Moses Glorino Rumambo Pandin ${ }^{2}$ \\ ${ }^{1}$ Faculty of Psychology, Airlangga University, Surabaya, Indonesia \\ ${ }^{2}$ Faculty of Cultural Studies, Airlangga University, Surabaya, Indonesia \\ rizki.alivia.putri-2020@psikologi.unair.ac.id; moses.glorino@fib.unair.ac.id
}

\begin{abstract}
Technological developments, as a result of globalization, indirectly affect human lifestyles, one of which is the Indonesian people. In a situation of change towards the Industrial Revolution 4.0, Pancasila has a role as a guide for the Indonesian people to be what by the noble values of the nation. However, the role of the millennial generation in maintaining these noble values is important considering that they are the spearhead of the country's development. From this statement, this study aims to identify and formulate steps to maintain the noble values of Pancasila among the millennial generation so that it does not eliminate national identity and understand the urgency of implementing the Pancasila lifestyle in the era of globalization. By using the literature review method, it can be seen that "grounding" and strengthening the essence of Pancasila values can be a solution so that the existence of Pancasila continues to shine. The Pancasila lifestyle deserves to be implemented because it regulates all behaviors of speech, thought, behavior, action, and good manners so that it must be expressed in the life of the nation and state as well as our everyday life.
\end{abstract}

\section{Keywords: Pancasila, Millennial Generation, Globalization}

\section{INTRODUCTION}

Pancasila, as the basis of the state, plays a role in regulating the behavior of the Indonesian people. In addition to being the basis and guideline for Indonesian society, Pancasila is also a value system that contains the noble values of the nation that originate from the cultural integration of the Indonesian people (12). and become the nation's main instrument because it can adapt to technological advances due to globalization. On the other hand, Pancasila is a value system that, among others, has one objective that is related to one another and is objective, subjective, and universal.

In a situation of change towards the 4.0 Industrial Revolution, Pancasila has a role as a guide for Indonesian society to conform to the noble values of the nation. As we know, globalization has become an era of change in which all aspects of life are progressing. The current 
globalization has begun to take root so that its influence cannot be simply eliminated (10). These influences can become a problem if not what by the personality and noble values of the nation, especially regarding lifestyle. This is where Pancasila plays as a filter to fortify itself from the negative effects of globalization.

Technological developments as a result of globalization indirectly affect human lifestyles, one of which is the Indonesian people. This makes the majority of Indonesian people become more consumptive and tend to be oriented towards western culture. They think that in the present era the fulfillment of tertiary needs is commonplace where it aims to improve the existence and quality of oneself in the groups they participate in (1). Of course, this is not in line with the noble values of Pancasila because it reflects the behavior of hedonism.

With a change-oriented situation to revolution 4.0, social order requires Pancasila as a way of life (10). Amid the negative impact of globalization, the only reliable guideline is Pancasila because Pancasila can be adapted to new situations as a result of globalization. From this statement, two questions arise: how important is the implementation of the Pancasila lifestyle among the millennial generation? What are the roles or steps that the millennial generation can take to realize and perpetuate the noble values of Pancasila? Both of these questions will be examined in this study through literature analysis. This article aims to identify and formulate steps to maintain the noble values of Pancasila among the millennial generation so as not to eliminate the nation's identity. This research is important considering that there are currently many negative impacts that we receive due to a lack of understanding of the essence of Pancasila itself. The importance of behaving with a Pancasila-style lifestyle must be immediately jointly promoted both from the community and the government so that all levels of the country can work together to formulate what needs to be prepared and the steps to realize and perpetuate the noble values of Pancasila, especially for the current millennial generation.

\section{METHODS}

This study uses a qualitative approach based on the theoretical framework, expert ideas, and the researcher's understanding with the literature review method (16). This literature review is a method that uses several references that are relevant to the research topic raised. The data 
collection technique used in this study uses documentation techniques (16) using secondary data in the form of a summary of 10 articles obtained from journals downloaded from Google Scholar in the 2019 to 2021 publication period with the help of the ATLAS.ti application to make it easier to correlate the issues raised with relevant theory or research. The data analysis technique used in this study is data reduction by focusing the search based on the topics discussed based on the 10 journal articles that have been mentioned (16). The keywords used in this study include "Pancasila", "millennial generation", and "globalization" using Boolean Operators (AND, OR, NOT).

Table 1 Literature Search Keywords

Pancasila

Millennial Generation

Golden generation

The values of Pancasila

AND

OR

The next generation

The Pancasila lifestyle

OR

OR

Gen-Z

Pancasila ideology

OR
Globalization

Technology changes

Industrial revolution 4.0

OR

In writing this article, the usage of inclusion criteria and exclusion criteria is acquired. In using the inclusion criteria, articles that are used as libraries are articles published during the period 2019 to 2021, researching Pancasila, the millennial generation, and globalization, and having full text access. On the other hand, in using the exclusion criteria for articles that are 
used as literature, articles published under 2019, do not discuss Pancasila, the millennial generation, and globalization, and do not have full-text access.

\section{RESULTS}

From the results of the literature study or literature review obtained, the authors found several studies that discuss the application of the Pancasila lifestyle which is focused on three keywords, namely Pancasila, the millennial generation, and globalization.

\section{Pancasila values}

The values of Pancasila are the embodiment of the noble character of the nation that has been inherited (5). The five precepts contained in Pancasila must be realized to all levels of society, especially the millennial generation. The values contained in the five precepts of Pancasila contain the principles of divinity, humanity, unity, democracy, and social justice. These values are a unified system that contains the basis for citizens to behave in the nation and state (5).

\section{Implementation of Pancasila values}

As the foundation of the state, Pancasila is the guideline in regulating all patterns of behavior and lifestyle of the people, especially for the millennial generation (9). The application of Pancasila is intended so that the noble values contained in Pancasila are not eroded by the influence of globalization. This is a marker or characteristic that can increase the sense of nationalism in the millennial generation.

The application of Pancasila values also aims to make Pancasila exist in the midst of the era of globalization. Pancasila has a role in maintaining the character and noble values of the nation, especially into the lifestyle of the millennial generation. The hope is that by applying the values of Pancasila, the lifestyle of the people, especially the millennial generation, does not conflict with Pancasila.

\section{The Urgency of Implementing Pancasila Values in Millennial Generation}

The millennial generation has a role in maintaining the existence of Pancasila values because it acts as the nation's next generation (14). The application of Pancasila in the era of 
globalization is important because it can maintain the existence of Pancasila (14). In addition, the values of Pancasila play a role in shaping identity so that it can be manifested in people's lifestyles. Pancasila is the foundation and foundation so that people hold fast to noble values so that the character possessed by the community is in accordance with Pancasila (10).

This is reinforced by research conducted by Azna (2021) which states that "earthing" or the introduction of Pancasila values to the millennial generation will form a future character of the nation that will continue to be imprinted in their hearts (15). By strengthening the values of Pancasila, it is hoped that the millennial generation will become the pillar of the nation's successor so that the noble values contained in Pancasila can still be maintained.

In line with the statements of Azna (2021) and Risdiani, et al. (2021) states that the strengthening of Pancasila can be started from a small scope such as family and school (15). This can be a solution to answer the demands of improving the character of the millennial generation based on Pancasila. Of course, this is the task of the millennial generation to perpetuate and apply the values of Pancasila.

\section{The Way That Can be Implemented by Millennial Generation}

The way that can be implemented to adopt a Pancasila lifestyle starts from an understanding of the values of Pancasila itself. In addition, other steps that can be applied are strengthening by improving and building noble character in accordance with the values of Pancasila in the millennial generation (8). Another way that can be taken to implement the Pancasila lifestyle is by implementing the Cultural and National Character Education program launched by the Ministry of Education and Culture in 2010.

\section{DISCUSSION}

Based on the research results that have been described, in the current era of globalization it is very important to adopt the Pancasila lifestyle among the millennial generation. Not without reason, in fact the longer the character possessed by the current millennial generation tends to conflict with the values of Pancasila (15). This of course can cause moral degradation and eliminate national identity.

The position of Pancasila is important for implementing its noble values among the millennial generation. Apart from being the basis of the state, Pancasila also acts as a national 
identity and a guide for the Indonesian nation to behave and speak. However, the real situation was not the case. The current millennial generation tends to be more interested in western culture and an anarchist culture. This does not reflect the implementation of Pancasila values. If this continues, Indonesia will lose its identity. Therefore, it is important to adopt a lifestyle pattern with Pancasila as early as possible so that all our movements reflect the real application of Pancasila (2).

The way that can be applied to adopt a Pancasila lifestyle starts from an understanding of the values of Pancasila itself. By interpreting the essence of Pancasila, our character will indirectly be guided by Pancasila which is full of noble values (3). From here, all our actions will automatically follow what is instilled in Pancasila.

In addition, other steps that can be applied are strengthening by improving and building noble characters that are by the values of Pancasila in the millennial generation (8). After starting to understand what the essence of Pancasila values are in their lifestyle, the characters that exist in the millennial generation need to be formed or improved again by applying aspects of citizenship and Pancasila in the hope that their spirit of nationalism will be formed first. Armed with this character, lifestyle behaviors that are contrary to the values of Pancasila will not be implemented by the millennial generation because they already have a mindset that the only guideline that can be used as a reference in dealing with the impact of globalization is Pancasila.

Pancasila as the basis of the state has contributed to forming a strong foundation in which the intercepts in it are complementary and interrelated (Setiawan, 2020). This is of course necessary to minimize the negative impact of globalization, especially in application among the millennial generation, considering that they are the golden generation at the forefront of national independence. Pancasila can act as a filter so that the millennial generation does not fall into the negative impacts of globalization. By implementing the values of Pancasila, a spirit of nationalism will be formed to face the great influence of globalization.

Most of the ethics and character of the millennial generation have begun to decline (11). This is marked by several events that occurred in Indonesia, for example, the existence of brawls, the perpetuation of a culture of corruption in schools, racism with another group, and also hatespeech behavior on social media. Little things like this if allowed to continue will be a disaster with a comprehensive impact. 
Another way that can be taken to implement the Pancasila lifestyle is by implementing the Cultural and National Character Education program launched by the Ministry of Education and Culture in 2010. However, we need to make reforms so that the programs launched are relevant to the current situation of globalization. This program is considered to have a big impact on "improving" the ethics and character of the millennial generation so that in the future they can participate in the process of building the country (5).

Currently, it is important to adopt a Pancasila lifestyle in everyday life. Not only that but we are also required to be role models for others to adopt the Pancasila lifestyle. The urgency of implementing a Pancasila lifestyle is very important because the situation in Indonesia in terms of character and lifestyle begins to contradict the values of Pancasila. Pancasila is the main indicator for building and improving the character of the millennial generation considering the precepts in Pancasila are a unified form that reflects the character and identity of the nation (10).

Judging from the current situation of globalization, the urgency of implementing the Pancasila lifestyle can be understood as something that must be realized in everyday life. The development of behavior by the values of Pancasila will later become a habit to create repetitive patterns that can be influenced by internal or even external factors (2). From this pattern of repetition, it will create a fixed structure of behavior that is by the values of Pancasila so that the existence of Pancasila amid globalization continues to shine because of the role of the millennial generation.

\section{CONCLUSION}

From the discussion that has been described, we can conclude that Pancasila has an important role as a reference or guide for the millennial generation in facing globalization. Although Pancasila has been formulated since Indonesia has not yet achieved its independence, the noble values contained in it can adapt to the times. Therefore, Pancasila is still relevant to be applied in the lifestyle of the millennial generation.

In addition, it can be concluded that Pancasila has an important role as a guide for the millennial generation in the life of the nation and state. This can be manifested in their lifestyle (10). In the literature it is stated that to apply the values of Pancasila it is necessary to "earth or socialize so that the essence of Pancasila is better understood by the current generation". 
The steps that can be taken to start implementing the Pancasila lifestyle are to understand the essence of implementing Pancasila values in the lifestyle of the millennial generation. In addition, strengthening by improving and building noble character with the values of Pancasila in the millennial generation is also important to implement.

In addition to taking these steps, millennials must understand the urgency of implementing Pancasila in their lifestyle. This is because the values of Pancasila are unique and authentic so that they can characterize the nation's identity. If the millennial generation maintains these values, the existence of Pancasila in the midst of globalization will not be extinguished. Pancasila deserves to be applied because it regulates all behavior of speech, thought, behavior, action, and good character so that it must be expressed in the life of the nation and state as well as our daily lives.

Overall, the limitation in this study is that it focuses more on the character of the millennial generation. In the future, as a refinement of this research, research with a wider object and covering all levels of Indonesian society can be carried out.

\section{REFERENCES}

1. Afrianto, Adrian P. Eksplorasi Kondisi Masyarakat dalam Memilih Belanja Online melalui Shopee Selama masa Pandemi Covid-19 di Indonesia. Jurnal Teknologi dan Informasi Bisnis. 2021, 31 Januari; 3(1): 10-29

2. Borgias, F., Stephanus Djunatan, Andreas Doweng Bolo, et al. Pancasila dalam Pendidikan Humaniora : Interkulturalisme dan Globalisasi. $1^{\text {st }}$ ed. Malang: Intelegensi Media; 2020

3. Tarmujianto. Implementasi Pancasila di Kalangan PNS Generasi Milenial dalam Menghadapi Pandemi Covid-19. JPK : Jurnal Pancasila dan Kewarganegaraan. 2021 Januari; 66 (1): 25-34

4. Hasanah U. Implementasi Nilai-Nilai Pancasila di Kalangan Generasi Millenial Untuk Membendung Diri Dari Dampak Negatif Revolusi Indutri 4.0. Pedagogy Jurnal Ilmiah Ilmu Pendidikan. 2021;8(1):52-9.

5. Risdianty, Hani \& Dewi, DA. Penguatan Karakter Bangsa sebagai Implementasi Nilai-Nilai Pancasila. Jurnal Pendidikan Indonesia. 2021, 4 April; 2(4): 696-711

6. Santika, IWE. Pendidikan Karakter Pembelajaran Daring. IVCEJ. 2020; 3(1): 8-19

7. Permatasari O.S., Hanita M., Perspektif Generasi Milenial Terhadap Pancasila. Jurnal Ilmu Hukum Dan Dinamika Masyarakat. 2021;19(1):30-43.

8. Fadilah, Nurul. Tantangan dan Penguatan Ideologi Pancasila dalam Menghadapi Era Revolusi Industri 4.0. Journal of Digital Education, Communication, and Arts. 2019, 30 September; 2(2): 66-78

9. Widiyanti, RA. Implementasi Nilai-Nilai Dasar Pancasila dalam dan Pasca Covid 19 Demi Menyongsong Era Adaptasi Kebiasaan Baru. Jurnal Pendidikan Sosial Keberagamaan. 2020; 7(2): 136-140 
10. Sallamah, D \& Dewi, DA. Peran dan Implementasi Nilai-Nilai Pancasila dalam Berkehidupan di Era Globalisasi. Antropocene : Jurnal Penelitian Ilmu Humaniora. 2021, Agustus; 1(8): 1-6

11. Septianingrum AD, Dewi DA. Implementasi Nilai Pancasila Pada Generasi Milenial Di Era Serba Modern. Jurnal Evaluasi dan Pembelajaran. Jurnal Evaluasi dan Pembelajaran. 2021;3(1):28-35.

12. Antari, LPS \& Liska, LD. Implementasi Nilai-Nilai Pancasila dalam Penguatan Karakter Bangsa. Widyadari: Jurnal Pendidikan. 2020, Oktober; 21(2): 676-687

13. Widiyaningrum, WY. Menumbuhkan Nilai Kesadaran Pancasila di Kalangan Generasi Muda : Kajian Teoritis. Jurnal JISIPOL. 2019, November; 3(3): 69-78

14. Lestari, EY, et al. Menumbuhkan Kesadaran Nasionalisme Generasi Muda di era Globalisasi Melalui Penerapan Nilai-Nilai Pancasila. Adil Indonesia Jurnal. 2019, Januari; 1(1): 20-27

15. Wulandari AD \& Dewi, DA. Urgensi Membumikan Pancasila Bagi Karakter Penerus Bangsa di Era Globalisasi. Jurnal Pendidikan Tambusai. 2021; 5(1): 926-930

16. Hardani, et. al. Metode Penelitian Kualitatif dan Kuantitatif. Yogyakarta: Pustaka Ilmu; 2020.

17. Azzahra, S. S., Pandin, M., \& Pandin, M. (2021). The factors of bullying and character education on teenagers. April, 1-9. https://doi.org/10.20944/preprints202104.0102.v1

18. Khansas, A., Kumala, D., \& Pandin, M. (2021). Archipelago Insights as Efforts to Establish National Geostrategic Resilience: A Literature Review. Preprints, May. https://doi.org/10.20944/preprints202105.0154.v1

19. Munir, M., Glorino, M., Pandin, R., Mada, U. G., Trilogi, U., Airlangga, U., Airlangga, U., \& Java, S.-E. (2020). Human Resource Information System and Work Stress during COVID-19 Pandemic. December, 1-14. https://doi.org/10.20944/preprints202012.0469.v1

20. Wicahyanti, P. A., Rahim, N. A., Glorino, M., \& Pandin, R. (2021). The Awareness of Millennial Generation during Covid-19 Pandemic towards State Defense Character. May, 112. https://doi.org/10.20944/preprints202105.0122.v1 


\section{ATTACHMENT}

Table 2 Summary of Research Results Based on 10 Articles Reviewed

No. Name, Author, Year, $\quad$ Research Results
Title of Research

1 Risdianty, Hani \& Dewi, Discussing the need for This study concludes that DA. (2021). Penguatan character strengthening as a the values of Pancasila Karakter Bangsa sebagai form of implementation of should be applied in the Implementasi Nilai-Nilai the values of Pancasila life of the nation and Pancasila. state.

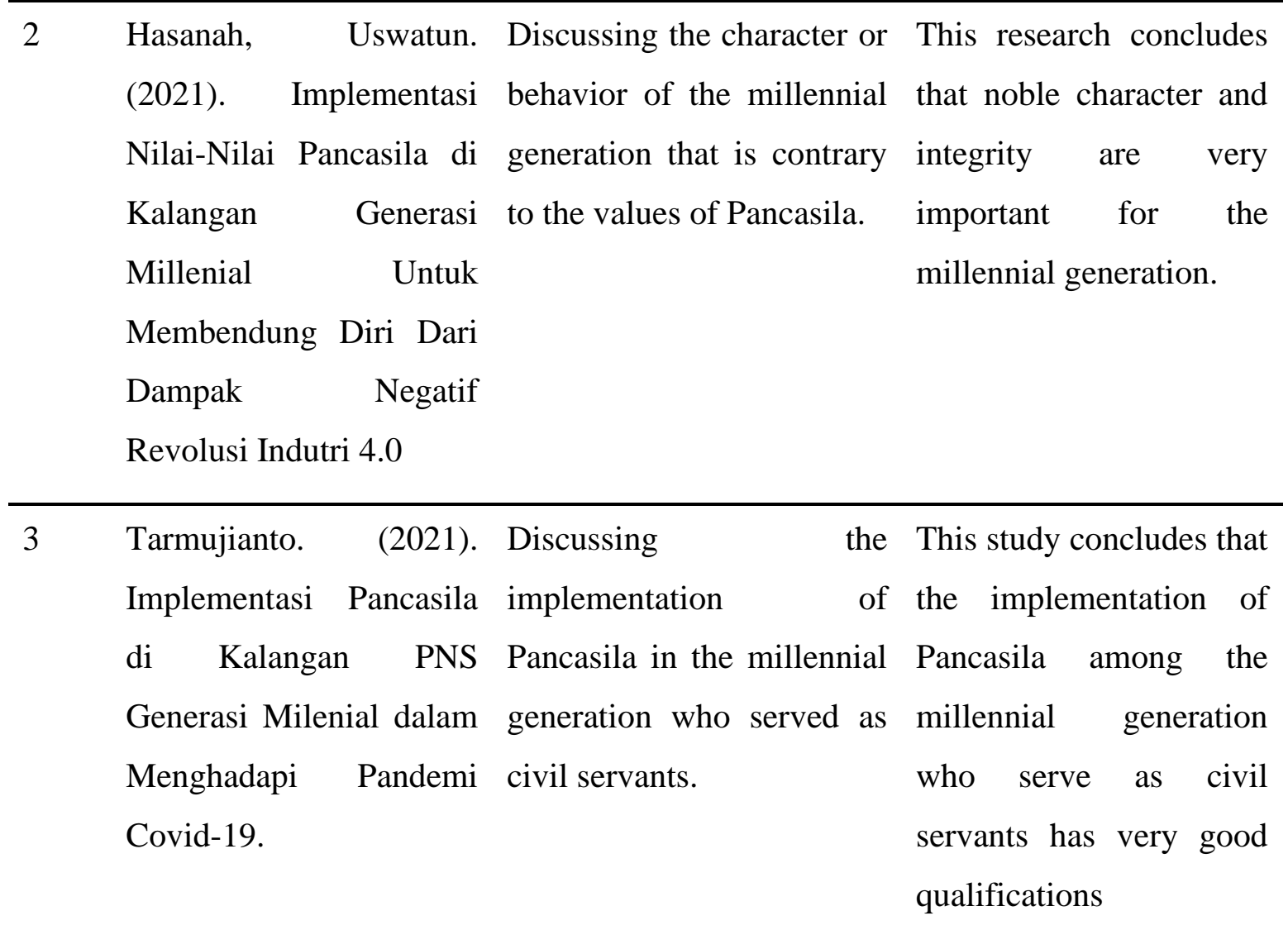


4 Santika, IWE. (2021). Discusses the importance This study concludes the

Pendidikan Karakter of character education in importance of the Pembelajaran Daring the millennial generation. teacher's role in shaping and revitalizing the character of the millennial generation.

5 Fadilah, Nurul. (2019). Discussing the role of the This study concludes that Tantangandan Penguatan Pancasila ideology in the there is a need for Ideologi Pancasila dalam face of the industrial strengthening by Menghadapi Era revolution 4.0 era grounding Pancasila in Revolusi Industri 4.0. citizens so that the noble values of Pancasila are maintained.

\begin{tabular}{ll}
\hline Septianingrum A.D., & Discussing the behavior of The conclusion of this \\
Dewi D.A. (2021). & the millennial generation study is that it is very \\
Implementasi Nilai & which is contrary to the important to apply \\
Pancasila Pada Generasi & values of Pancasila so that Pancasila values in the \\
Milenial Di Era Serba & real action is needed to modern era to the \\
Modern & implement these values in millennial generation \\
& the modern era..
\end{tabular}


7 Widiyanti, RA. (2020). Discussing the application This study concludes that Implementasi Nilai-Nilai of Pancasila values amid the implementation of Dasar Pancasila dalam globalization and post- Pancasila values is still dan Pasca Covid 19 Demi Covid-19 relevant to the current Menyongsong Era situation of globalization Adaptasi Kebiasaan even though it is in a Baru. pandemic period.

8 Permatasari O.S., Hanita Discussing the perspective This study concludes that M. (2021). Perspektif of the millennial generation the millennial generation Generasi Milenial on Pancasila is still difficult to Terhadap Pancasila. understand the essence and application of Pancasila values due to the language that is not easily understood.

9 Sallamah, D \& Dewi, Discussing the role and This study concludes that DA. (2021). Peran dan implementation of the millennial generation Implementasi Nilai-Nilai Pancasila in the era of still has a difficulty in Pancasila dalam globalization understanding the Berkehidupan di Era essence and application Globalisasi. of Pancasila values due to the language that is not easily understood. 
10 Wulandari AD \& Dewi, Discussing the urgency of This study concludes that DA. (2021). Urgensi applying Pancasila values Pancasila must be the Membumikan Pancasila to the nation's future foundation for its citizens Bagi Karakter Penerus generations to behave and live. Bangsa di Era Globalisasi 